J. Lake Sci. (湖泊科学) , 2016, 28(6): 1194-1203

DOI 10. 18307/2016. 0605

(c) 2016 by Journal of Lake Sciences

\title{
太湖流域流经不同类型缓冲带入湖河流秋、冬季氮污染特征
}

\author{
胡小贞, 耿荣妹, 许秋瑾, 蒋丽佳, 林娜娜 \\ (中国环境科学研究院, 北京 100012)
}

\begin{abstract}
摘 要: 为研究太湖流经不同类型缓冲带的人湖河流水体氮污染特征, 于 2011 年 $9-12$ 月连续对流经 4 种不同类型缓冲 带人湖河流沿程共 32 个样点进行采样, 分析各样点的氮浓度及变化趋势. 结果表明, 流经农田型缓冲带人湖河流中总氮 浓度由缓冲带外进入缓冲带内不断减小, 到入湖河口处有轻微上升; 流经养殖塘型、村落型缓冲带入湖河流中总氮浓度 由缓冲带外进入缓冲带内变化不大, 到接近人湖河口时浓度显著升高; 流经生态型缓冲带人湖河流中各氮元素形态沿程 不断降低. 在流经 4 种类型湖泊缓冲带人湖河流中, 流经农田型、养殖塘型和生态型缓冲带的人湖河流以硝态氮为氮元 素的主要存在形态,而流经村落型缓冲带的人湖河流中硝态氮和铵态氮同为氮元素的主要存在形态. 总氮浓度、铵态氮 浓度与缓冲带类型均呈极显著正相关关系,外源污染排人对流经缓冲带的人湖河流中氮元素总量及形态产生较大影响. 流经生态型缓冲带人湖河流净化效果最佳,总氮、硝态氮和铵态氮浓度削减率分别为 $60 \%, 53 \%$ 和 $61 \%$.
\end{abstract}

关键词: 湖泊缓冲带;富营养化;太湖流域;氮污染;人湖河流

\section{Charactistics of nitrogen pollution of rivers flowing through different lake buffer strips in autumn/winter, Taihu Basin}

HU Xiaozhen, GENG Rongmei, XU Qiujin, JIANG Lijia \& LIN Nana

(Lake Engineering Research Centre, Chinese Research Academy of Environmental Sciences, Beijing 100012, P.R.China)

\begin{abstract}
In order to study the nitrogen pollution characteristics in rivers flowing through different lake buffer zones, thirty-two sites of four rivers flowing through the buffer zones of Lake Taihu were sampled and analyzed continuously from September to December in 2011. The results showed that total nitrogen (TN) reduced from outside to inside the buffer zones in rivers flowing through types of farmland, while appeared slight increase at lake estuary. As far as both the river flowing through the pond type buffer zone and the river through the village type buffer, the TN concentrations had nearly no change along the flow direction from outside of buffer zone to the inside of buffer zone, except a significant increase in the lake estuary area. However, the concentrations of all kinds of nitrogen along the river in the lake which flows through the ecological type buffer was reduced gradually. Among rivers flowing through buffer strips of four different types, nitrate nitrogen $\left(\mathrm{NO}_{3}^{-}-\mathrm{N}\right)$ was the dominant form of nitrogen element in types of farmland, aquaculture ponds and ecological, while $\mathrm{NO}_{3}^{-}-\mathrm{N}$ and ammonium nitrogen $\left(\mathrm{NH}_{4}^{+}-\mathrm{N}\right)$ were both the dominant forms of nitrogen element in type of village zone. Both $\mathrm{TN}$ and $\mathrm{NH}_{4}^{+}-\mathrm{N}$ showed significant positive correlation with the types of buffer zone. Pollution from these buffer zones discharged into rivers had a significant impact on the total amount and form of nitrogen. The ecological-type buffer zone has the best purification ability, with $\mathrm{TN}, \mathrm{NO}_{3}^{-}-\mathrm{N}$ and $\mathrm{NH}_{4}^{+}-\mathrm{N}$ concentration reduction rates were $60 \%$, $53 \%$ and $61 \%$, respectively.
\end{abstract}

Keywords: Lake buffer zones; type division; eutrophication; Taihu Basin ; nitrogen pollution; inflow rivers

湖泊缓冲带是指高于湖泊、水库等水体最高水位线以上的部分陆域地区,具体范围在不同的水体中会 有所差异 ${ }^{[1]}$. 湖泊缓冲带是湖泊湖滨带外围的保护圈 ${ }^{[2]}$,健康完善的湖泊缓冲带具有隔离和缓冲、拦截净化 低污染水、调节地表径流、保护物种多样性、固岸护坡作用、景观功能和经济功能等多种功能 ${ }^{[3]}$. 在 1960s 后 期,美国首先提出缓冲带的概念并加以运用, 指出将近岸区域的水体环境与人类活动进行有效隔绝的缓冲

* 国家水体污染控制与治理科技重大专项 (2014ZX07510-001-01,2013ZX07101-014-04) 资助. 2015 - 10 - 15 收稿; 2016-03-15 收修改稿.胡小贞 (1975 ), 女, 硕士, 副研究员;E-mail: huxz@ craes.org.cn. 
区域即为缓冲带 ${ }^{[4]} .1980 \mathrm{~s}$ 中后期, 湖泊缓冲带研究已在美国、日本等国家得到较快发展, 在确定河湖水体的 缓冲带宽度范围、缓冲带的植被种类及其净化效益相关性、缓冲带管理及功能等领域展开深人的探究 ${ }^{[5-9]}$. 如 Hill 等 ${ }^{[10]}$ 研究指出, 湖岸带生态系统退化直接导致其蓄藏和拦截过滤功能的丧失是造成河流和湖泊富营 养化的一个重要原因; Lowrance 等 ${ }^{[11]}$ 研究表明, 湖岸带生态系统不仅可以有效吸收径流水样中携带的氮磷 等污染物,还可以通过络合、鳌合作用削减地下水中的持久性污染物,同时吸附大量泥沙颗粒及其中的重金 属和有机污染物; Peterjohn 等 ${ }^{[12-14]}$ 研究发现, 湖泊缓冲带可以起到减缓径流速度、防止水流侵蚀、促进泥沙 沉积以及滞留并降解其中大量的氮磷营养物质的功能. 一旦湖泊缓冲带遭到破坏, 对湖泊和人湖河流的影 响十分巨大,所以对其开展研究具有重要意义.

太湖是苏、浙、晥、沪等诸多大城市的重要的供水水源地和淡水资源来源地. 近几十年来, 随着太湖流域 人为活动的日益加剧、经济发展及农村建设使太湖缓冲带的生态功能和结构过程受到干扰和破坏. 目前太 湖缓冲带土地利用类型中, 农田所占比重最高, 农田面源污染是太湖水体重要污染源之一; 城镇农村、工交 建设用地和水库坑塘也带来了较大污染 ${ }^{[15]}$. 湖泊缓冲带不但起不到应有的净化作用, 由于缓冲带的污染, 其本身还成为污染产生的 “源”, 并加速了流经缓冲带的河流的污染. 太湖外源氮污染中,农业面源污染占的 比重最大 ${ }^{[16]}$, 其次是生活污水和养殖污水 ${ }^{[17-19]}$. 朱广伟 ${ }^{[20]}$ 研究表明太湖水体总氮浓度在人湖河口区明显高 于其他湖区, 毛战坡等 ${ }^{[21]}$ 研究氮素在河流生态系统中的滞留作用, 韩梅等 ${ }^{[22]}$ 研究环太湖主要河流氮素组成 特征及来源, 表明溶解态无机氮是氮素的主要存在形式. 本文通过研究太湖流域流经不同土地利用现状的 缓冲带河流水体氮沿程污染特征, 剖析不同土地利用现状缓冲带对过境人湖河流水质的影响, 旨在为科学 分析人为侵占对缓冲带带来的污染问题, 为有针对性地进行缓冲带污染控制和生态修复提供支撑.

\section{1 研究区概况与研究方法}

\section{1 研究区概况}

太湖 ( $30^{\circ} 56^{\prime} \sim 31^{\circ} 54^{\prime} \mathrm{N}, 119^{\circ} 54^{\prime} \sim 120^{\circ} 36^{\prime} \mathrm{E}$ ) 作为我国五大淡水湖之一, 位于江苏省南部, 长江三角洲的 中部, 全部水域在江苏省境内, 湖水南部与浙江省湖州市相连. 流域面积 $36500 \mathrm{~km}^{2}$, 湖泊面积 $2427.8 \mathrm{~km}^{2}$, 实际水域面积 $2338 \mathrm{~km}^{2}$, 南北长 $68.5 \mathrm{~km}$, 东西平均宽 $34 \mathrm{~km}$, 湖岸线总长 $405 \mathrm{~km}$, 平均水深 $2 \mathrm{~m}$ 左右, 总蓄水 量为 $47.6 \times 10^{8} \mathrm{~m}^{3}$.

根据“太湖缓冲带生态建设研究”子课题组 2010 年的研究成果,按太湖缓冲带内土地利用现状将太湖 缓冲带分为农田型、村落型、养殖塘型、生态防护林型、景区型共 5 种类型 ${ }^{[23]}$, 其中农田型缓冲带岸线长 $121.75 \mathrm{~km}$, 占整个缓冲带长度的 $31.8 \%$; 村落型长度 $99.6 \mathrm{~km}$, 占 $26.0 \%$; 养殖塘型长 $67.43 \mathrm{~km}$, 占 $17.6 \%$; 生 态防护林型长 $60.87 \mathrm{~km}$, 占 $15.9 \%$, 景区型长度 $33.1 \mathrm{~km}$, 占 $8.6 \%$. 研究结果显示, 农田型、鱼塘型、村落型缓 冲带是太湖缓冲带现状的主要类型, 占太湖缓冲带总长度的 $75.6 \%$.

\section{2 研究方法}

1.2 .1 点位设置 在剖析太湖缓冲带的生态环境结构和功能特点后, 依据缓冲带的分类, 选取 4 种类型缓冲 带典型区段, 包括农田型缓冲带-庙渎港, 养殖塘型缓冲带-林庄港, 村落型缓冲带-葛渎港, 生态型缓冲带庙港, 分别在这 4 种类型的缓冲带外上溯 $1 \mathrm{~km}$ 、缓冲带内及缓冲带人湖口区域布点, 于 2011 年 9-12 月进 行每月 1 次的采样调查, 以此分析太湖不同类型缓冲带的污染现状. 采样时用麦哲伦海王星型定位仪进行 导航定位. 环太湖不同类型缓冲带内典型区段采样点的编号、位置、所处区域及流经的河流名称如图 1 所示. 1.2.2 样品采集与分析 用玻璃采水器采集河流表层水样, 采集后迅速运回实验室低温保存, 样品储存在洁 净塑料采样瓶里, 当天测定总氮 $(\mathrm{TN})$ 、铵态氮 $\left(\mathrm{NH}_{4}^{+}-\mathrm{N}\right)$ 和硝态氮 $\left(\mathrm{NO}_{3}^{-}-\mathrm{N}\right)$ 浓度, 相对标准偏差在 $10 \%$ 以内.

\section{2 结果分析}

\section{1 流经农田型缓冲带的河流水体氮污染特征分析}

从水质沿程变化来看, 缓冲带外、缓冲带内和人湖河口均为劣 $\mathrm{V}$ 类水质. 从氮及其不同形态沿程变化来 看, 流经农田型缓冲带的河流 TN 月均值浓度沿程呈先降低后在人湖河口略微回升趋势, 缓冲带内 TN 浓度 较缓冲带外明显降低, 二者间的降幅均值约 $42 \%$; $\mathrm{NO}_{3}^{-}-\mathrm{N}$ 月均值浓度沿程由缓冲带外到缓冲带内再到人湖 


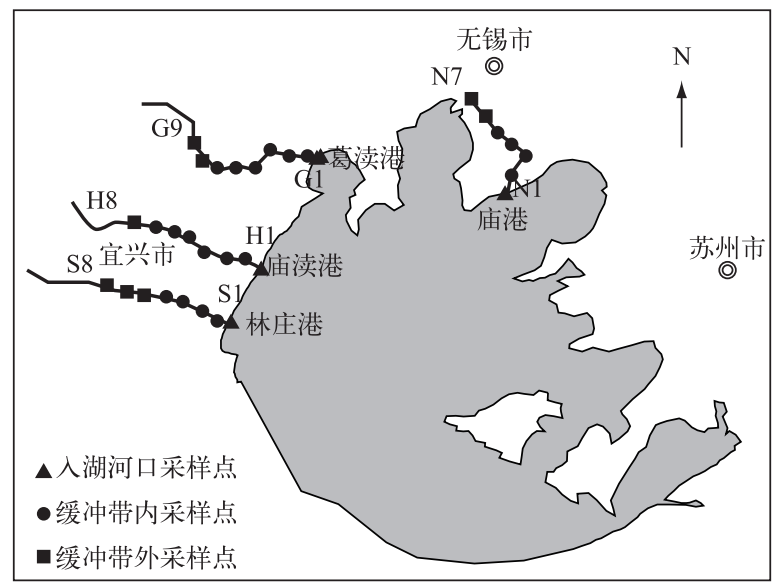

图 1 太湖不同类型缓冲带人湖河流样点布设

Fig.1 Distribution of sampling sites in rivers flowing through different lake buffer zones

河口不断减小, 降幅均值分别为 $48 \% 、 29 \%$; 各样点的 $\mathrm{NH}_{4}^{+}-\mathrm{N}$ 月均值浓度相对较低, 变化趋势不明显. 从氮的 不同形态来看,在本研究区段内 $\mathrm{NO}_{3}^{-}-\mathrm{N}$ 月均值浓度占 $\mathrm{TN}$ 月均值浓度的百分比范围为 $37 \% \sim 75 \%$,均值为 $56 \%$; 而 $\mathrm{NH}_{4}^{+}-\mathrm{N}$ 月均值浓度占 $\mathrm{TN}$ 月均值浓度的百分比范围为 7\% 16\%, 均值为 $12 \%$ (图 2a). $\mathrm{NO}_{3}^{-}-\mathrm{N}$ 是农 田型缓冲带人湖河流中氮元素的主要存在形态.

人湖河流水体中 TN 浓度 9-12 月的沿程变化趋势与月均值一致, 即缓冲带外 >人湖河口>缓冲带内, 其 中 10 月份 TN 浓度均高于其它 3 个月份对应区段, 9 月份各区段的 TN 浓度显著低于其它 3 个月份对应区 段. $\mathrm{NO}_{3}^{-}-\mathrm{N}$ 浓度 4 个月的沿程变化趋势与月均值基本一致,其中 12 月份各区段的 $\mathrm{NO}_{3}^{-}-\mathrm{N}$ 浓度均高于其他 3 个月份的对应区段, 9 月份各区段的 $\mathrm{NO}_{3}^{-}-\mathrm{N}$ 浓度显著低于其他 3 个月份的对应区段. $\mathrm{NH}_{4}^{+}-\mathrm{N}$ 浓度 4 个月的 沿程变化趋势没有明显的规律性, 9 月份 $\mathrm{NH}_{4}^{+}-\mathrm{N}$ 浓度较低, 其他月份沿程变化幅度大, 没有明显的规律性 (图 2b d).

\section{2 流经养殖塘型缓冲带的河流水体氮污染特征分析}

从水质沿程变化来看, 缓冲带外、缓冲带内和人湖河口均为劣 $\mathrm{V}$ 类水质. 从氮及其不同形态沿程变化来 看, 进人养殖塘型缓冲带后 $\mathrm{TN} 、 \mathrm{NO}_{3}^{-}-\mathrm{N}$ 和 $\mathrm{NH}_{4}^{+}-\mathrm{N}$ 浓度月均值变化不大, 到接近人湖河口浓度显著升高. 从氮 的不同形态来看, 在本研究区段内 $\mathrm{NO}_{3}^{-}-\mathrm{N}$ 月均值浓度占 $\mathrm{TN}$ 月均值浓度的百分比范围为 $41 \% \sim 55 \%$, 均值为 $48 \%$; 而 $\mathrm{NH}_{4}^{+}-\mathrm{N}$ 月均值浓度占 $\mathrm{TN}$ 月均值浓度的百分比范围为 $6 \% \sim 13 \%$,均值为 $9 \% . \mathrm{NO}_{3}^{-}-\mathrm{N}$ 是养殖塘型缓 冲带人湖河流中氮元素的主要存在形态 (图 3a).

$\mathrm{TN}$ 浓度在 9 月份和 10 月份的沿程变化趋势与月均值略为不同, 9 月份 $\mathrm{TN}$ 浓度表现为缓冲带外 <缓冲 带内<八湖河口, 10 月份 TN 浓度表现为缓冲带外>缓冲带内 $>$ 人湖河口, 而其它两个月份的沿程变化趋势与 月均值基本一致. $\mathrm{NO}_{3}^{-}-\mathrm{N}$ 浓度 4 个月的沿程变化趋势与月均值大体一致, 其中 12 月份 $\mathrm{NO}_{3}^{-}-\mathrm{N}$ 浓度变动幅度 较大,各区段 (除 $\mathrm{S} 4$ 点位外) 的 $\mathrm{NO}_{3}^{-}-\mathrm{N}$ 浓度值均高于其他 3 个月份对应区段; 10 月份 $\mathrm{NO}_{3}^{-}-\mathrm{N}$ 浓度较低,各区 段 (除 $\mathrm{S} 4 、 \mathrm{~S} 8$ 点位外) 的 $\mathrm{NO}_{3}^{-}-\mathrm{N}$ 浓度低于其他 3 个月份对应区段. 4 个月的缓冲带内 $\mathrm{NH}_{4}^{+}-\mathrm{N}$ 浓度较缓冲带外 均有下降的趋势, 其中 12 月份各区段 (除 $\mathrm{S} 3$ 点位外) 的 $\mathrm{NH}_{4}^{+}-\mathrm{N}$ 浓度均高于其他 3 个月份对应区段, 9、10月 份的 $\mathrm{NH}_{4}^{+}-\mathrm{N}$ 浓度较低(图 3b d).

\section{3 流经村落型缓冲带的河流水体氮污染特征分析}

从水质沿程变化来看, 缓冲带外、缓冲带内和人湖河口均为劣 $\mathrm{V}$ 类水质. 从氮及其不同形态沿程变化来 看, 进人村落型缓冲带后 $\mathrm{TN}$ 和 $\mathrm{NH}_{4}^{+} \mathrm{-N}$ 月均值浓度变化不大, 到 $\mathrm{G} 4$ 点位开始回升, $\mathrm{TN}$ 月均值浓度上升趋势 明显; $\mathrm{NO}_{3}^{-}-\mathrm{N}$ 月均值浓度从缓冲带内 $\mathrm{G} 5$ 点位开始大幅降低, 到入湖河口回升. 从氮的不同形态来看, 缓冲带 内 $\mathrm{NO}_{3}^{-}-\mathrm{N}$ 月均值浓度占 $\mathrm{TN}$ 月均值浓度的百分比范围为 $13 \% \sim 55 \%$, 均值为 $26 \%$; 而缓冲带内 $\mathrm{NH}_{4}^{+}-\mathrm{N}$ 月均 

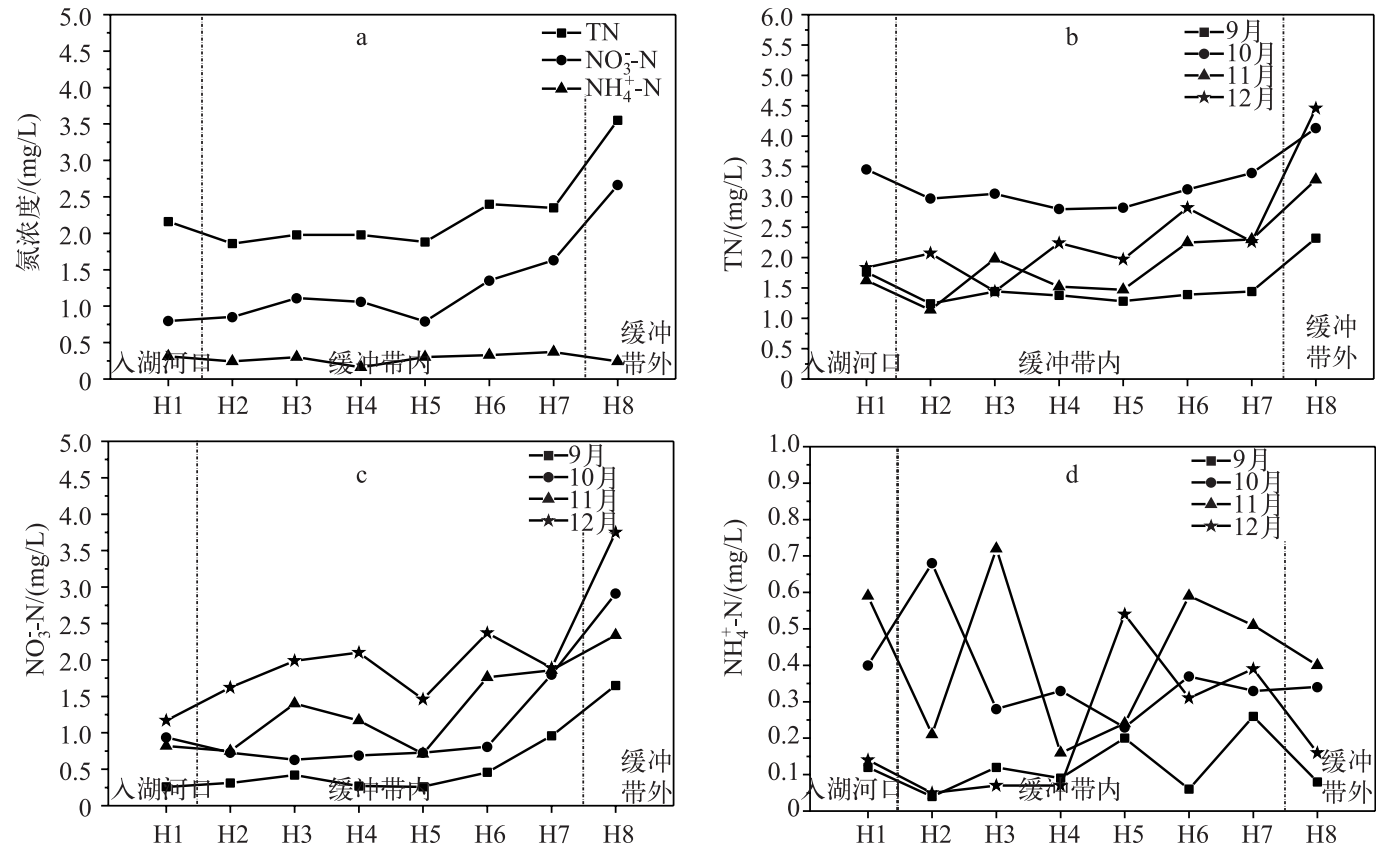

图 2 流经农田型缓冲带河流 $\mathrm{TN} 、 \mathrm{NO}_{3}^{-}-\mathrm{N}$ 和 $\mathrm{NH}_{4}^{+}-\mathrm{N}$ 浓度沿程变化

Fig.2 Changes of $\mathrm{TN}, \mathrm{NO}_{3}^{-}-\mathrm{N}$ and $\mathrm{NH}_{4}^{+}-\mathrm{N}$ concentrations in rivers flowing through buffer zones of farmland type
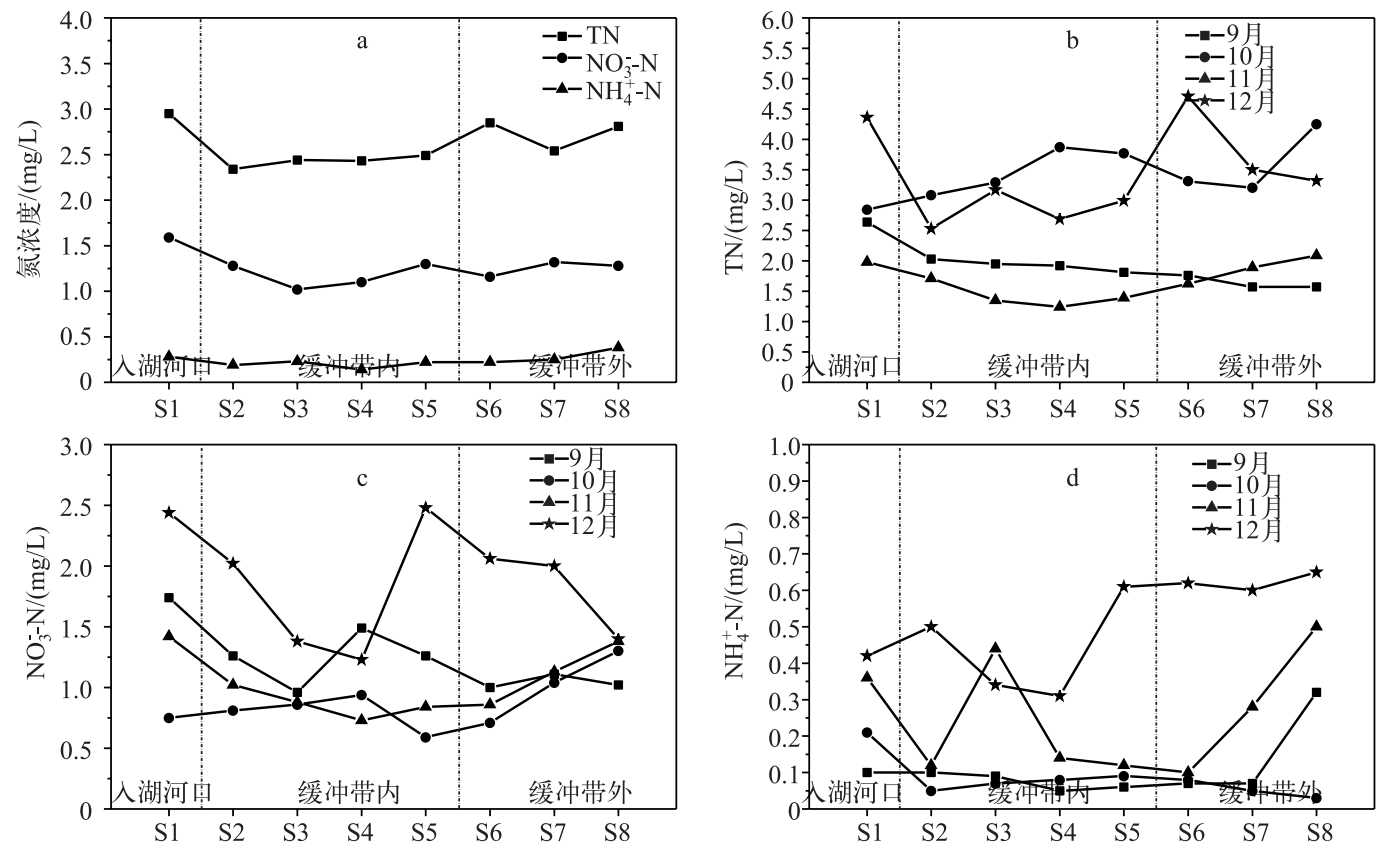

图 3 流经养殖塘型缓冲带河流 $\mathrm{TN} 、 \mathrm{NO}_{3}^{-}-\mathrm{N}$ 和 $\mathrm{NH}_{4}^{+}-\mathrm{N}$ 浓度沿程变化

Fig. 3 Changes of $\mathrm{TN}, \mathrm{NO}_{3}^{-}-\mathrm{N}$ and $\mathrm{NH}_{4}^{+}-\mathrm{N}$ concentrations in rivers flowing through buffer zones of aquaculture ponds type 
值浓度占 TN 月均值浓度的百分比范围为 $17 \% \sim 30 \%$,均值为 $23 \%$, 可见 $\mathrm{NH}_{4}^{+}-\mathrm{N}$ 和 $\mathrm{NO}_{3}^{-}-\mathrm{N}$ 在村落型缓冲带 中所占地位相当 (图 4a).

$\mathrm{TN}$ 浓度在 9、10 月份的沿程变化趋势与月均值略为不同, 表现为缓冲带外<缓冲带内 $<$ 人湖河口, 10 月 份各区段大部分点位的 TN 浓度高于其他 3 个月份对应区段, 11 月份缓冲带内和人湖河口 TN 浓度低于其 他 3 个月份对应区段 (除 $\mathrm{G} 6 、 \mathrm{G} 7$ 点位外). $\mathrm{NO}_{3}^{-}-\mathrm{N}$ 浓度 4 个月的沿程变化趋势与月均值大体一致,缓冲带内 $\mathrm{NO}_{3}^{-}-\mathrm{N}$ 浓度降低趋势明显. 缓冲带内 $\mathrm{NH}_{4}^{+}-\mathrm{N}$ 浓度在 $9 、 10$ 月份大于缓冲带外, 在 $11 、 12$ 月份小于缓冲带外 $\mathrm{NH}_{4}^{+}-\mathrm{N}$ 浓度, 10 月份缓冲带内 $\mathrm{NH}_{4}^{+}-\mathrm{N}$ 浓度较高, 12 月份缓冲带内 $\mathrm{NH}_{4}^{+}-\mathrm{N}$ 浓度较低 (图 4b d).
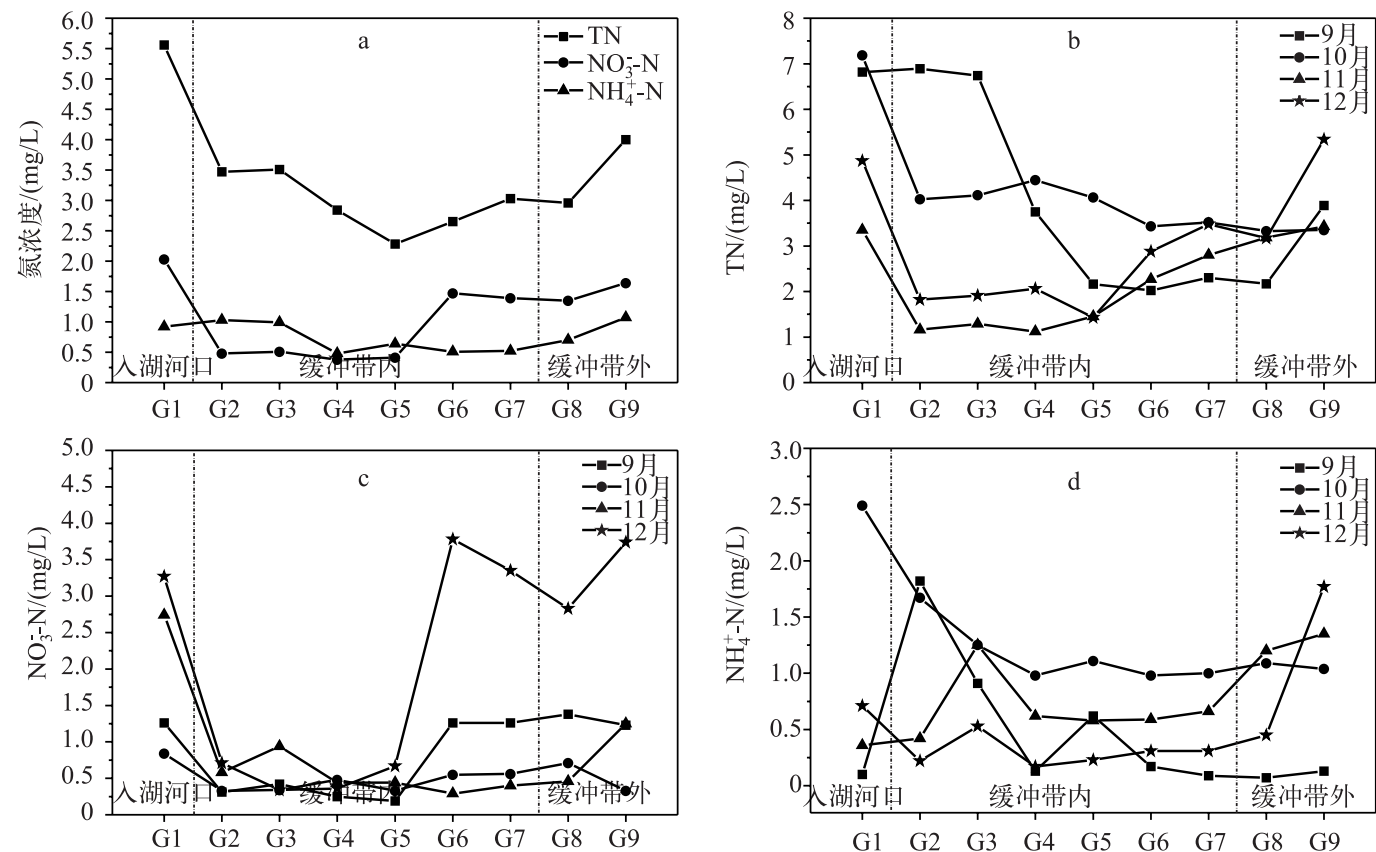

图 4 流经村落型缓冲带河流 $\mathrm{TN} 、 \mathrm{NO}_{3}^{-}-\mathrm{N}$ 和 $\mathrm{NH}_{4}^{+}-\mathrm{N}$ 浓度沿程变化

Fig.4 Changes of $\mathrm{TN}, \mathrm{NO}_{3}^{-}-\mathrm{N}$ and $\mathrm{NH}_{4}^{+}-\mathrm{N}$ concentrations in rivers flowing through buffer zones of villages type

\section{4 流经生态型缓冲带的河流水体氮污染特征分析}

从水质沿程变化来看, 缓冲带外为劣 $\mathrm{V}$ 类水质, 缓冲带内水质好转为 $\mathrm{V}$ 类, 至人湖河口处水质进一步好 转为 $\mathrm{IV}$ 类. 从氮及其不同形态沿程变化来看, 流经生态型缓冲带的河流水体 $\mathrm{TN} \mathrm{NO}_{3}^{-}-\mathrm{N}$ 和 $\mathrm{NH}_{4}^{+}-\mathrm{N}$ 月均值浓 度均沿程逐渐降低, 总削减率分别为 $60 \%$ 、 $53 \%$ 和 $61 \%$. 从氮的不同形态来看, 缓冲带内 $\mathrm{NO}_{3}^{-}-\mathrm{N}$ 月均值浓度 占 $\mathrm{TN}$ 月均值浓度的百分比范围为 $46 \% \sim 63 \%$, 均值为 $49 \%$; 而缓冲带内 $\mathrm{NH}_{4}^{+}-\mathrm{N}$ 月均值浓度占 $\mathrm{TN}$ 月均值浓 度的百分比范围为 $16 \% \sim 31 \%$,均值为 $27 \%$. $\mathrm{NO}_{3}^{-}-\mathrm{N}$ 是生态型缓冲带中氮元素的主要存在形态 (图 $5 \mathrm{a}$ ).

$\mathrm{TN}$ 浓度 4 个月的沿程变化趋势与月均值一致, 不同月份间差异不明显. $\mathrm{NO}_{3}^{-}-\mathrm{N}$ 浓度在 $9 、 10$ 月份的沿 程变化趋势与月均值略为不同, 缓冲带外 $\mathrm{NO}_{3}^{-}-\mathrm{N}$ 浓度小于缓冲带内; $11 、 12$ 月份与月均值一致, 即 $\mathrm{NO}_{3}^{-}-\mathrm{N}$ 浓 度由大到小依次为缓冲带外>缓冲带内>人湖河口,其中 12 月份各区段大部分点位的 $\mathrm{NO}_{3}^{-}-\mathrm{N}$ 浓度高于其他 3 个月份的对应区段. 4 个月的 $\mathrm{NH}_{4}^{+}-\mathrm{N}$ 浓度缓冲带内小于缓冲带外, 10 月份缓冲带内 $\mathrm{NH}_{4}^{+}-\mathrm{N}$ 浓度最高, 12 月份缓冲带内 $\mathrm{NH}_{4}^{+}-\mathrm{N}$ 浓度最低( 图 5b d). 

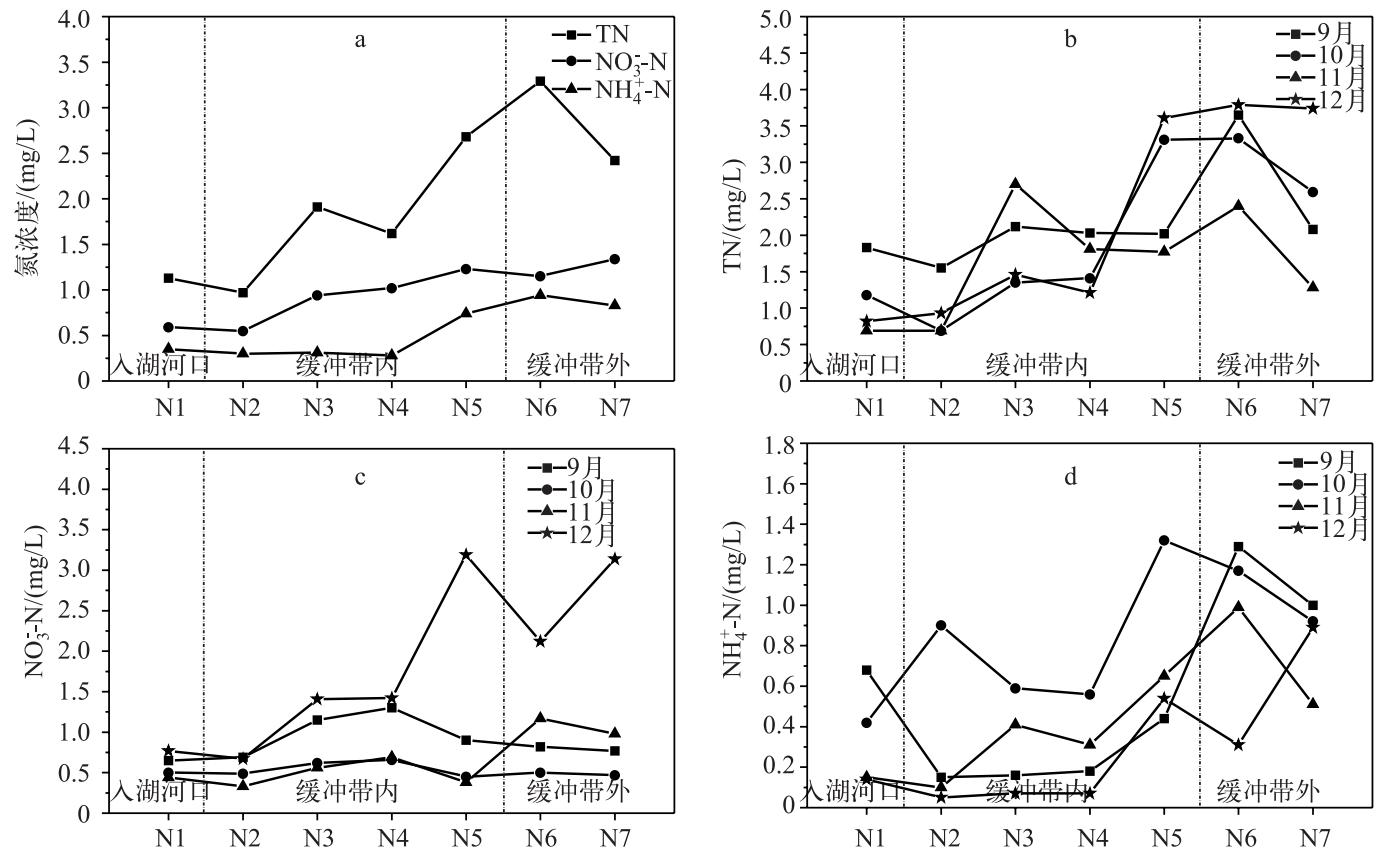

图 5 流经生态型缓冲带河流 $\mathrm{TN} 、 \mathrm{NO}_{3}^{-}-\mathrm{N}$ 和 $\mathrm{NH}_{4}^{+}-\mathrm{N}$ 浓度沿程变化

Fig.5 Changes of $\mathrm{TN}, \mathrm{NO}_{3}^{-}-\mathrm{N}$ and $\mathrm{NH}_{4}^{+}-\mathrm{N}$ concentrations in rivers flowing through buffer zones of ecology type

\section{3 讨论}

\section{1 流经不同类型缓冲带入湖河流水体中氮元素时间变化特征}

从氮形态来看, 流经 4 种类型缓冲带人湖河流的典型区段中, $\mathrm{TN} \mathrm{NO}_{3}^{-}-\mathrm{N}$ 和 $\mathrm{NH}_{4}^{+}-\mathrm{N}$ 浓度在 9-12 月份内 均有大幅变化且变化规律有所差异, TN 浓度在 10 月份最高, 11 月份有所下降后在 12 月份又回升,流经村 落型缓冲带的人湖河流中 TN 浓度最高(图 6). 农田型缓冲带内由于肥料氮元素的累积及植物的衰败, 流经 其人湖河流中 $\mathrm{NO}_{3}^{-}-\mathrm{N}$ 浓度随时间逐渐升高, 流经其他 3 种类型缓冲带人湖河流 $\mathrm{NO}_{3}^{-}-\mathrm{N}$ 浓度在 $9 、 10$ 月份略 有下降, 在 12 月份大幅增长. 流经养殖塘型缓冲带人湖河流 $\mathrm{NH}_{4}^{+} \mathrm{-N}$ 浓度随时间基本呈不断升高趋势, 流经 其他 3 种类型缓冲带人湖河流 $\mathrm{NH}_{4}^{+}-\mathrm{N}$ 浓度基本在 10 月份达到最高值, 随后不断减小. 流经村落型缓冲带人 湖河流中由于有大量生活用水汇人, $\mathrm{NH}_{4}^{+}-\mathrm{N}$ 浓度最高.

$9 、 10$ 月份处于雨季, 降雨量大, 对 $\mathrm{N}$ 起到一定程度的稀释作用 ${ }^{[24]}$, 反硝化作用引起水体氮素损失 ${ }^{[25]}$, 且植物生长旺盛, 有大量的 $\mathrm{N}$ 被吸收, 从而导致人湖河流水体中 $\mathrm{N}$ 浓度降低; 而 $11 、 12$ 月份降雨量小, 植物 生长基本停止, 吸收 $\mathrm{N}$ 营养物质能力大幅下降, 反硝化作用减弱, 同时植物休眠和腐解等现象使生长季节吸 收的 $\mathrm{N}$ 重新被释放, 从而导致水体中 $\mathrm{N}$ 浓度升高. 养殖塘和村落均为雨季排水, 养殖废水和农村生活污水含 有大量 $\mathrm{N}$, 通过渗流或径流排人入湖河流, 使 $9 、 10$ 月份养殖塘型和村落型缓冲带内人湖河流的 $\mathrm{N}$ 较缓冲带 外大幅升高.

\section{2 流经不同类型缓冲带的入湖河流水体中氮元素空间分布特征}

流经 4 种类型湖泊缓冲带各区段的人湖河流 $\mathrm{TN} 、 \mathrm{NO}_{3}^{-}-\mathrm{N}$ 和 $\mathrm{NH}_{4}^{+}-\mathrm{N}$ 浓度月均值沿程变化趋势各有不同, 流经农田型缓冲带人湖河流 $\mathrm{NO}_{3}^{-}-\mathrm{N}$ 浓度最高, $\mathrm{TN}$ 及 $\mathrm{NH}_{4}^{+}-\mathrm{N}$ 浓度沿程呈先减小后增大的趋势, $\mathrm{NO}_{3}^{-}-\mathrm{N}$ 浓度 沿程不断减小; 流经养殖塘型缓冲带人湖河流 $\mathrm{NH}_{4}^{+}-\mathrm{N}$ 浓度最低, 各氮元素形态沿程呈先减小后增大趋势, 人 湖河口处浓度略大于缓冲带外; 流经村落型缓冲带人湖河流 $\mathrm{TN}$ 及 $\mathrm{NH}_{4}^{+} \mathrm{N}$ 浓度最高, 各氮元素形态沿程亦 呈先减小后增大趋势, 但人湖河口处浓度远大于缓冲带外浓度; 流经生态型缓冲带人湖河流 $\mathrm{TN}$ 及 $\mathrm{NO}_{3}^{-}-\mathrm{N}$ 浓 


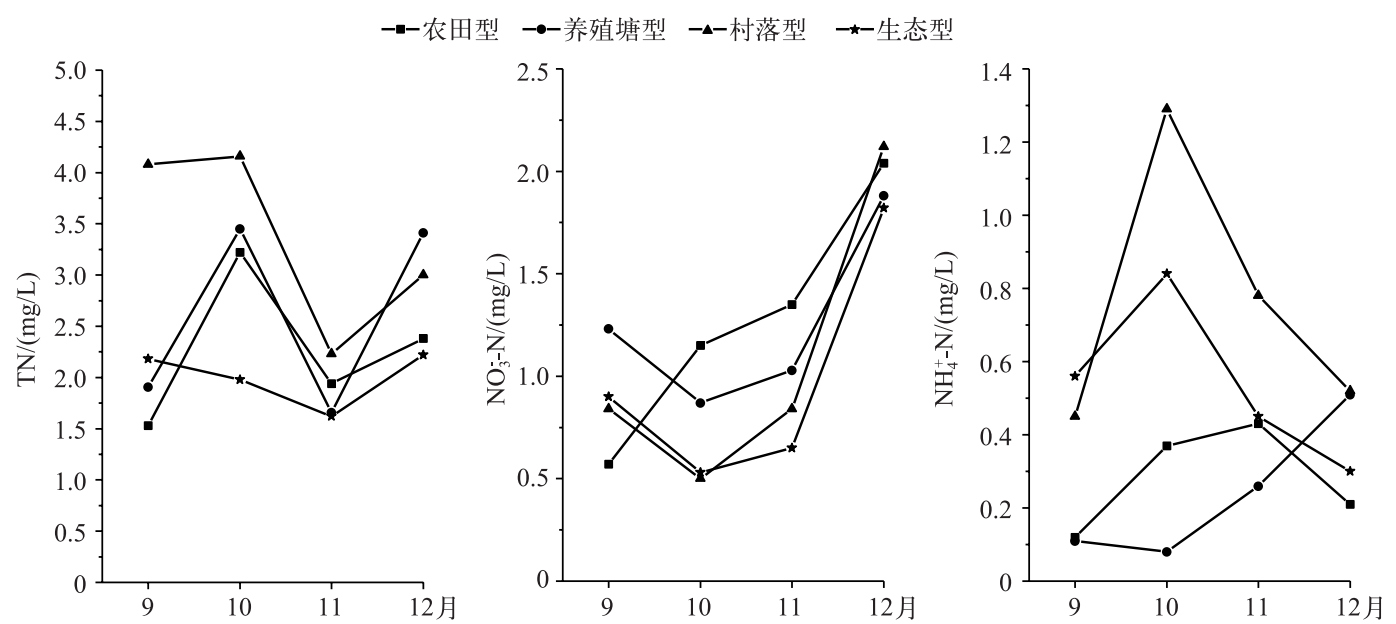

图 6 流经 4 种类型缓冲带人湖河流 $\mathrm{TN} 、 \mathrm{NO}_{3}^{-}-\mathrm{N}$ 和 $\mathrm{NH}_{4}^{+}-\mathrm{N}$ 浓度时间变化

Fig.6 Time variation of $\mathrm{TN}, \mathrm{NO}_{3}^{-}-\mathrm{N}$ and $\mathrm{NH}_{4}^{+}-\mathrm{N}$ concentrations in rivers flowing through buffer zones of four types 度最低, 各形态氮沿程不断减小, 净化效果最佳 (图 7). 根据上述结果, 农田型缓冲带人湖河流中 TN 由缓冲 带外进人缓冲带内浓度不断减小, 到人湖河口处有轻微上升, 该类型缓冲带对氮污染具有一定的削减作用; 养殖塘型、村落型缓冲带人湖河流中总氮由缓冲带外进人缓冲带内浓度变化不大, 到接近人湖河口时浓度 显著升高; 流经生态型缓冲带入湖河流中各形态氮沿程不断降低.
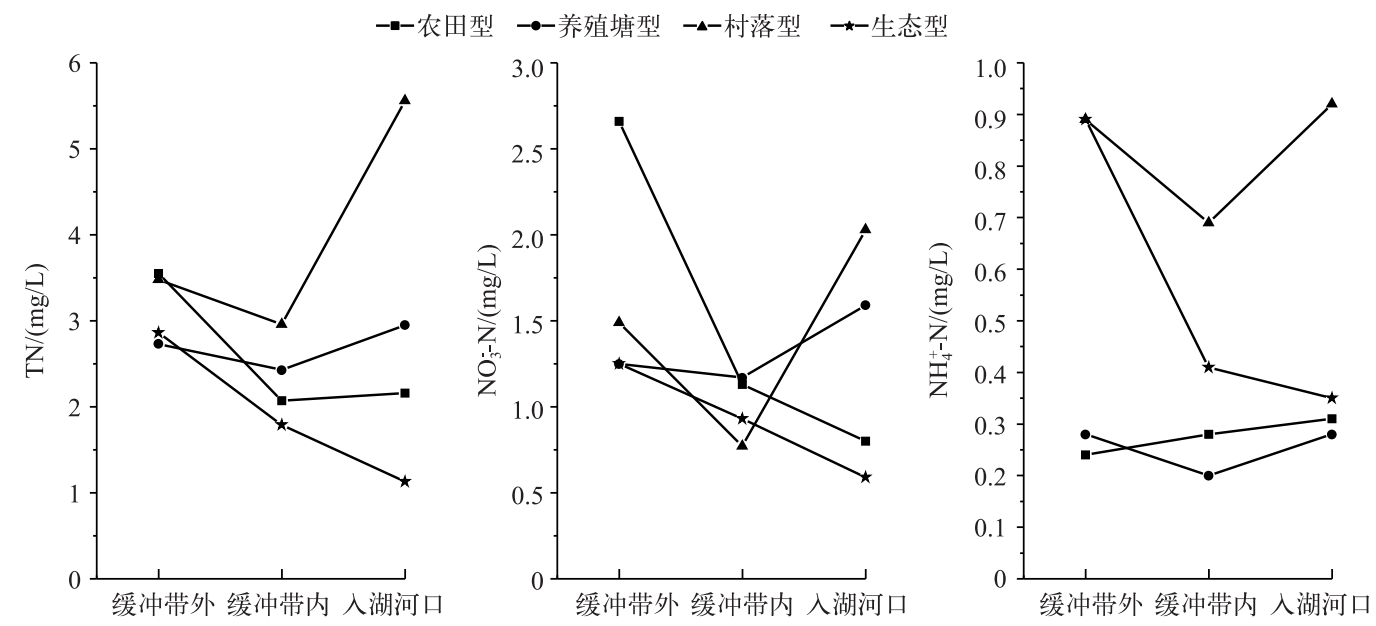

图 7 流经 4 种类型缓冲带人湖河流 $\mathrm{TN} 、 \mathrm{NO}_{3}^{-}-\mathrm{N}$ 和 $\mathrm{NH}_{4}^{+}-\mathrm{N}$ 浓度空间分布

Fig.7 Spatial distribution of $\mathrm{TN}, \mathrm{NO}_{3}^{-}-\mathrm{N}$ and $\mathrm{NH}_{4}^{+}-\mathrm{N}$ concentrations in rivers flowing through buffer zones of four types

农田型缓冲带主要污染来源于农田的季节性施肥及植物腐败, 但调查时间不是农田施肥季节, 且农田 植物对污染物具有削减作用. 村落型缓冲带所处区域周边居民区较为集中, 土地的开发利用强度也比较大, 加之污染物排放强度的增加, 周边区域土地的缓冲能力较差, 使得流经村落型缓冲带入湖河流污染严重. 养 殖塘型缓冲带是以鱼塘、蟹塘以及自然形成的小型坑塘为主, 本次调查的林庄港途经丁蜀镇汤庄村的水产 自然村, 当地居民养殖塘内的蟹塘出水和鱼塘出水处理后用作周围农田或林地的灌溉用水, 最后流人河流 内, 引起缓冲区内河流水质的变化. 村落型和养殖塘型缓冲带人湖河口处水质均达到劣 V 类, 甚至高于缓冲 带外的水质, 原因是人湖河流进人湖泊前, 人湖河口与大湖体闸门封闭, 缓冲带排人人湖河流中污染物在此 
累积, 湖泊河口污染较严重, 溶解氧含量低, 影响硝化和反硝化作用的进行 ${ }^{[26]}$, 导致人湖河口的水质变差.

\section{3 不同类型缓冲带入湖河流中氮元素相关性分析}

氮在水中以 4 种形态存在: 有机氮、 $\mathrm{NH}_{4}^{+}-\mathrm{N} 、 \mathrm{NO}_{3}^{-}-\mathrm{N}$ 和 $\mathrm{NO}_{2}^{-}-\mathrm{N}, \mathrm{NO}_{3}^{-}-\mathrm{N}$ 和 $\mathrm{NH}_{4}^{+}-\mathrm{N}$ 是主要迁移形态 ${ }^{[21]}$. 氮 的转化包括氨化、同化、硝化和反硝化作用,不同水环境因素对氮的转化可产生促进或抑制作用. 不同类型 缓冲带入湖河流中氮浓度与外源污染负荷排入量和水体自净能力等有关, 其污染量及污染物形态都有所差 异. 为研究人湖河流流经缓冲带后, 水中氮污染及迁移演变过程, 以缓冲带总氮排污系数作为其类型表征, 对不同类型缓冲带中河流水体进行氮元素的相关性分析.

河流水体中氮素的输出方式一是通过常规反硝化或戻氧氨氧化作用生成氮气从水体去除, 二是通过吸 附或沉积作用固定下来 ${ }^{[27]}$. $\mathrm{TN} 、 \mathrm{NH}_{4}^{+}-\mathrm{N}$ 浓度与缓冲带类型均呈极显著正相关 $(P<0.01)$, 表明缓冲带外源污 染排人对流经缓冲带的人湖河流中氮元素总量及形态产生很大影响 (表 1). 农田型缓冲带氮污染源主要为 施肥、牲畜禽粪便和植物腐解, 化肥的过量使用是农业营养盐产生量增加以及农业面源污染最直接的原因; 养殖塘型缓冲带氮污染源为养殖塘阶段清塘排水; 村落型缓冲带氮污染源主要为生活污水和生活垃圾, $\mathrm{NH}_{4}^{+}-\mathrm{N}$ 浓度所占比重较其他类型缓冲带高. $\mathrm{NO}_{3}^{-}-\mathrm{N}$ 浓度与缓冲带类型没有明显相关关系, 可能是由于 $\mathrm{NO}_{3}^{-}-\mathrm{N}$ 在每种缓冲带氮污染中均占较大比重.

$\mathrm{TN}$ 浓度与水环境因素没有明显的相关性, 说明水环境因素主要对氮形态产生影响. $\mathrm{NO}_{3}^{-}-\mathrm{N}$ 浓度与 $\mathrm{NH}_{4}^{+}-\mathrm{N}$ 浓度一方面取决于外源排人量, 另一方面也取决于水体内氨化反应、硝化反应以及反硝化反应. $\mathrm{NO}_{3}^{-}-\mathrm{N}$ 浓度与 $\mathrm{DO}$ 浓度呈极显著正相关 $\left(R^{2}=0.328, P<0.01\right), \mathrm{NH}_{4}^{+}-\mathrm{N}$ 浓度与 DO 浓度呈显著负相关 $\left(R^{2}=\right.$ $0.284, P<0.05)$,与硝化反应、反硝化反应机理一致.

表 1 流经不同类型缓冲带人湖河流中氮元素相关性分析

Tab.1 Correlation analysis of nitrogen in rivers flowing through lake buffer zones

\begin{tabular}{|c|c|c|c|c|c|c|c|}
\hline 相关因子 & $\mathrm{TN}$ & $\mathrm{NO}_{3}^{-}-\mathrm{N}$ & $\mathrm{NH}_{4}^{+}-\mathrm{N}$ & 缓冲带类型 & 水温 & $\mathrm{pH}$ 值 & DO \\
\hline $\mathrm{TN}$ & 1 & & & & & & \\
\hline $\mathrm{NO}_{3}^{-}-\mathrm{N}$ & 0.043 & 1 & & & & & \\
\hline $\mathrm{NH}_{4}^{+}-\mathrm{N}$ & $0.524^{* *}$ & -0.219 & 1 & & & & \\
\hline 缓冲带类型 & $0.357^{\text {*** }}$ & -0.185 & $0.460^{* * *}$ & 1 & & & \\
\hline 水温 & 0.178 & $-0.458^{* * *}$ & 0.074 & 0.049 & 1 & & \\
\hline $\mathrm{pH}$ 值 & -0.040 & $0.237^{*}$ & -0.014 & $0.250^{*}$ & $-0.568^{* * *}$ & 1 & \\
\hline DO & -0.160 & $0.328^{* *}$ & $-0.284^{*}$ & 0.150 & $-0.477^{\text {*** }}$ & $0.714^{* *}$ & 1 \\
\hline
\end{tabular}

* 表示在 0.05 水平 $($ 双侧 $)$ 上显著相关, ** 表示在 0.01 水平 (双侧) 上显著相关.

\section{4 结论}

1) 流经农田型缓冲带的人湖河流中 TN 浓度由缓冲带外进人缓冲带内不断减小, 到人湖河口处有轻微 上升; 流经养殖塘型、村落型缓冲带人湖河流中 $\mathrm{TN}$ 浓度由缓冲带外进人缓冲带内变化不大, 到接近人湖河 口时浓度显著升高;流经生态型缓冲带人湖河流中各氮元素形态沿程不断降低.

2) 在流经 4 种类型湖泊缓冲带人湖河流中, 流经农田型、养殖塘型和生态型缓冲带人湖河流以 $\mathrm{NO}_{3}^{-}-\mathrm{N}$ 为氮元素的主要存在形态, 分别占 TN 浓度的 $56 \% 、 48 \%$ 和 $49 \%$, 远远大于 $\mathrm{NH}_{4}^{+}-\mathrm{N}$ 浓度; 而流经村落型缓冲带 人湖河流 $\mathrm{NO}_{3}^{-}-\mathrm{N}$ 和 $\mathrm{NH}_{4}^{+}-\mathrm{N}$ 分别占 $\mathrm{TN}$ 浓度的 $26 \%$ 和 $23 \%$,两者同为氮元素的主要存在形态.

3) $\mathrm{TN}$ 浓度、 $\mathrm{NH}_{4}^{+}-\mathrm{N}$ 浓度与缓冲带类型均呈极显著正相关关系, 缓冲带外源污染排人对流经缓冲带的人 湖河流中氮浓度及形态产生很大影响.

4) 根据流经 4 种类型湖泊缓冲带的人湖河流水质判断, 流经生态型缓冲带人湖河流净化效果最佳, 水 质由劣 $\mathrm{V}$ 类好转为 $\mathrm{IV}$ 类, 其 $\mathrm{TN} 、 \mathrm{NO}_{3}^{-}-\mathrm{N}$ 和 $\mathrm{NH}_{4}^{+}-\mathrm{N}$ 浓度总削减率分别为 $60 \% 、 53 \%$ 和 $61 \%$.

\section{5 参考文献}

[ 1 ] Hu Xiaozhen, Xu Qiujin, Jiang Lijia et al. A preliminary study on demarcation limits of lake buffer zones: A case study of 
Lake Taihu. J Lake Sci, 2011, 23(5) : 719-724(in Chinese with English abstract). DOI: 10.18307/2011.0508. [ 胡小 贞, 许秋瑾, 蒋丽佳等. 湖泊缓冲带范围划定的初步研究——太湖为例. 湖泊科学, 2011, 23(5): 719-724.]

[ 2 ] Rao Liangyi, Cui Jianguo. Research advances on the eco-hydrological functions of riparian buffer. Science of Soil and Water Conservation, 2008, 6(4): 121-128(in Chinese with English abstract). [ 饶良懿, 崔建国. 河岸植被缓冲带生态水文 功能研究进展. 中国水土保持科学, 2008, 6(4) : 121-128.]

[ 3 ] Jin Xiangcan ed. Technology guide of ecological restoration about and lakeside zone and buffer zones. Beijing: Science Press, 2014: 13-17 (in Chinese). [ 金相灿. 湖滨带与缓冲带生态修复工程技术指南. 北京: 科学出版社, 2014: 13-17.]

[ 4 ] Tara R, Stephen RC. Comparisons of p-yield, riparian buffer strips, and land cover in six agricultural watersheds. Ecosystems, 2002, 5: 568-577.

[ 5 ] Barfield BJ, Blevins RL, Fogle AW et al. Water quality impacts of natural filter strips in karst areas. Transactions of the American Society of Agricultural Engineers, 1998, 41(2) : 371-381.

[ 6 ] Bavor HJ, Roser DJ, Adcock PW. Challenges for the development of advanced constructed wetlands technology. Water Science and Technology, 1995, 32(3): 13-20.

[ 7 ] Anna L, Bradley L, Ross G. Bat activity on riparian zones and upper slopes in Australian timber production forests and the effectiveness of riparian buffers. Biological Conservation, 2006, 129: 207-220.

[ 8 ] Schoonover JE, Williard KWJ, Zaczek JJ. Nutrient attenuation in agricultural surface runoff by riparian buffer zones in Southern Illinois, USA. Agroforestry Systems, 2005, 64: 169-180.

[ 9 ] Lowrance R, McIntyre S, Lance C. Erosion and deposition in a field/forest system estimated using cesium-137 activity. Journal of Soil and Water Conservation, 1988, 43: 195-199.

[10] Hill AR, Devito KJ. Subsurface denitrification in a forest riparian zone: Interactions between hydrology and supplies of nitrate and organic carbon. Biogeochemistry, 2000, 51: 193-223.

[11] Lowrance RT, Lance C. Erosion and deposition in a field/forest system estimated using cesium-137 activity. Journal of Soil and Water Conservation, 1988, 43: 195-199.

[12] Peterjohn WT, Correll DL. Nutrient dynamics in an agricultural watershed: Observations on the role of riparian forest. Ecology, 1984, 65: 1475-1499.

[13] Yang Shengtian, Wang Xuelei, Liu Changming et al. Recent advances in the study of riparian ecosystems. Acta Scientiae Circumstantiae, 2007, 27(6) : 894-905(in Chinese with English abstract). [ 杨胜天, 王雪蕾, 刘昌明等. 岸边带生态 系统研究进展. 环境科学学报, 2007, 27(6): 894-905.]

[14] Guo Huaicheng, Huang Kai, Liu Yong et al. A conceptual framework and its key issues for ecosystem management of riparian zones. Geographical Research, 2007, 26(4) : 789-798(in Chinese with English abstract). [ 郭怀成, 黄凯, 刘永等. 河岸带生态系统管理研究概念框架及其关键问题. 地理研究, 2007, 26(4) : 789-798.]

[15] Dong Siyuan, Xu Qiujin, Hu Xiaozhen et al. Current land utilization and changes of Taihu buffer zones. Agro-Environment \& Development, 2014, 4: 62-64 (in Chinese with English abstract). [ 董思远, 许秋瑾, 胡小贞等. 太湖缓冲带土地利用 现状及变化. 农业环境与发展, 2014, 4: 62-64.]

[16] Li Hengpeng, Yang Guishan, Huang Wenyu. Simulating study of nitrogen amounts into the lake in Taihu upstream. Acta Pedologica Sinica, 2007, 44(6) : 1063-1069 (in Chinese with English abstract). [李恒鹏, 杨桂山, 黄文钜. 太湖上游 地区面源污染氮素人湖量模拟研究. 土壤学报, 2007, 44(6): 1063-1069.]

[17] Li Ronggang, Xia Yuanling, Wu Anzhi et al. Pollutants sources and their discharging amount in Taihu Lake area of Jiangsu Province. J Lake Sci, 2000, 12(2): 147-153(in Chinese with English abstract). DOI: 10.18307/2000.0208. [李荣刚, 夏源陵, 吴安之等. 江苏太湖地区水污染物及其向水体的排放量. 湖泊科学, 2000, 12(2) : 147-153.]

[18] Xiong Zhengqin, Xing Guangtao, Shen Guangyu et al. Non-point source N pollution of lakes rivers and wells in the Taihu Lake region. Rural Eco-Environment, 2002, 18(2) : 29-33 (in Chinese with English abstract). [熊正琴, 邢光喜, 沈光 裕等. 太湖地区湖、河和井水中氮污染状况的研究. 农村生态环境, 2002, 18(2): 29-33.]

[19] Xu Gang, Zhu Zhenguo, Huang Jianguang et al. Effects of socio-economic development on the water environment in Wuxi City, Taihu Watershed. J Lake Sci, 2002, 14(2) : 173-179( in Chinese with English abstract). DOI: 10.18307/2002. 0211. [许刚, 朱振国, 黄建光等. 无锡市社会经济发展对水环境的影响. 湖泊科学, 2002, 14(2): 173-179.

[20] Zhu Guangwei. Eutrophic status and causing factors for a large, shallow and subtropical Lake Taihu, China. J Lake Sci, 
2008, 20(1) : 21-26(in Chinese with English abstract). DOI: 10.18307/2008.0103. [ 朱广伟. 太湖富营养化现状及 原因分析. 湖泊科学, 2008, 20(1): 21-26.]

[21] Mao Zhanpo, Shan Baoqing, Peng Wenqi et al. Progress of nitrogen retention in the river ecosystem. Resources and Environment in the Yangtze Basin, 2006, 15(4) : 480-484(in Chinese with English abstract). [毛战坡, 单保庆, 彭文启等. 氮素在河流生态系统中的滞留研究进展. 长江流域资源与环境, 2006, 15(4) : 480-484.]

[22] Han Mei, Zhou Xiaoping, Cheng Yuanhua et al. Study on the sources and characteristics of nitrogen in the major rivers of Taihu Lake. Research of Environmental Sciences, 2014, 27(12): 1450-1457(in Chinese with English abstract). [ 韩梅, 周小平, 程媛华等. 环太湖主要河流氮素组成特征及来源. 环境科学研究, 2014, 27(12): 1450-1457.]

[23] Xu Qiujin, Hu Xiaozhen, Jiang Lijia. Present situation and ecological construction of Taihu buffer zones. Beijing: Science Press, 2015: 107-140(in Chinese). [许秋瑾, 胡小贞, 蒋丽佳. 太湖缓冲带现状与生态构建. 北京: 科学出版社, 2015: 107-140. ]

[24] Xu H, Paerl HW, Qin BQ et al. Nitrogen and phosphorus inputs control phytoplankton growth in eutrophic Lake Taihu, China. Limnology and Oceanography, 2010, 55: 420-432.

[25] McCarthy MJ, Lavrentyev PL, Yang L et al. Nitrogen dynamics relative to microbial food web structure in a subtropical, shallow, well-mixed, eutrophic lake. Hydrobiologia, 2007, 581: 195-207.

[26] Jin Xiangcan, Xin Weiguang, Lu Shaoyong et al. Effect of polluted inflow river on water quality of lake Bay. Research of Environmental Sciences, 2007, 20(4) : 52-56(in Chinese with English abstract). DOI : 10.13198/j.res.2007.04.56.jinxc. 010. [金相灿, 辛玮光, 卢少勇等. 人湖污染河流对受纳湖湾水质的影响. 环境科学研究, 2007, 20(4) : 52-56. ]

[27] Wu Yali, Xu Hai, Yang Guijun et al. Progress in nitrogen pollution research in Lake Taihu. J Lake Sci, 2014, 26(1) : 19-28 (in Chinese with English abstract). DOI: 10.18307/2014.0103. [吴雅丽, 许海, 杨桂军等. 太湖水体氮素污染 状况研究进展. 湖泊科学, 2014, 26(1) : 19-28.] 